\title{
Cleaner Production Implementation in the Textile Sector: The Case of a Medium-sized Industry in Minas Gerais
}

\author{
Nelma Penha da Costa, José Francisco Prado Filho e Alberto Fonseca \\ Universidade Federal de Ouro Preto \\ nelmapcosta@yahoo.com.br; jfprado@depro.em.ufop.br; albertof@em.ufop.br
}

\begin{abstract}
Textile industries have been increasingly adopting cleaner production strategies, particularly in developed countries. In Brazil and globally, there are arguably few publications addressing this phenomenon. This study aimed at understanding the extent to which industries from textile sector implement cleaner production strategies, based on an empirical analysis of a particular medium-sized industry in the state of Minas Gerais, Brazil. A checklist of cleaner production opportunities, drawn from the literature, was analyzed in the context of the selected industry. Data were collected through interviews and field surveys. This study identified cleaner production opportunities for textiles industries, and pointed out a number most feasible actions. The study also identified that cleaner production can work as an effective environmental management framework for medium-sized industries. However, depending on the particular aspects of each industry, cleaner production actions may be perceived as technically and economically unviable. In the particular case study analyzed here, the most implemented actions were those that required low investments and that were not technically demanding. Findings from this study suggest that cleaner production can drive proactive environmental efforts, resulting in technological and economic benefits. However, findings also suggest that such benefits may not be easily obtained, particularly in the context of industries that still work with out-of-date technology.
\end{abstract}

Keywords: Cleaner production; Textile sector; Environmental management; Social Responsibility; Brazil 


\section{INTRODUCTION}

For millennia, civilizations have been using natural resources to attend their many needs, such as feeding, home sheltering and transportation. However, until a few decades ago, concerns around wastes, emissions and other "side-effects" of production were rare. Solid wastes, for example, tented to be simply discarded without any meaningful environmental control (GIANNETTI and ALMEIDA, 2006). However, the appropriate disposal of wastes has become an important beacon of current-day industry. According to Philippi Jr. et al. (2004), due to rapid population growth in the past decades, there has been an overwhelming increase in raw material and energy supply-demand and, therefore, stronger outputs of wastes and emissions. According to Giffoni and Lange (2005), daily global generation of wastes is in the order of millions of tons.

Sisinno (2003) argues that, in the contemporary world, it is essential the appropriate management of wastes by all social spheres (public, private and community), through the establishment of waste management policies to ensure sound treatment and destination, that are both economically and environmentally feasible.

In Brazil, even after Federal Law 12.305/2010, which enacted the National Policy of Solid Wastes, many companies still consider their waste management activities as an unimportant piece within their industrial production process. Planning and deciding on internal environmental structures and policies, which give support to the stages of a product, service or even of a technological development process, are not yet considered as a relevant factor to the success of such organizations (PHILLIPPI Jr. et al., 2004).

However, this scenario tends to change. The adoption of proactive environmental behavior by industries, by focusing on the prevention of waste generation and aiming lowing costs to its destination and treatment, reduction of material and energy use, has already started to take place on particular industrial sites, thus turning their processes more eco-efficient. According to Giannetti and Almeida (2006), eco-efficiency is the production of goods and services at a competitive price, progressively lowering environmental impact and exploitation under a bearable level supported by the planet.

In the past years, there have been many concepts and principles applied to the minimization of environmental impacts by industries. Among these, is the concept of 'Cleaner Production' (CP), also known in Brazil as P+L (in Portuguese, Produção + Limpa). This concept is used to describe strategies of industrial environmental management which enable the company to operate in a social and environmentally responsible way, positively influencing their economic and technological results (SILVA FILHO and SICSÚ, 2003).

The implementation of ' $\mathrm{CP}$ ' strategies has been increasingly investigated all over the world: a fact that is mirrored in the growing output of articles in the international Journal of Cleaner Production. In Brazil, however, few studies have addressed the CP trend, particularly in the textile sector. To address this knowledge gap, this study evaluated the implementation of CP strategy in a medium-sized Brazilian textile industry. More specifically, it aimed at understanding the extent to which a particular textile industry implemented various $\mathrm{CP}$ opportunities. The results presented further on, are likely to appeal to national and global scholars interested in the general topic of CP strategies, particularly as they relate to the "under-researched" textile sector. Scholars and policy-makers interested in voluntary and social responsibility policies are also likely to find relevance in this study's findings.

\section{CONCEPT OF CLEANER PRODUCTION (CP)}

The literature offers many definitions to the $\mathrm{CP}$ concept. However, as it has been observed by Hilson (2003), in general, this concept has been used, particularly in Europe, Australia, and Asia, to describe approaches to environmental management highly connected to the principle of "prevention". The CP concept was spread in the 80's by UNEP (United Nations Environment Program) and UNIDO (United Nations Industrial Development Organization), as an attempt to operationalize sustainable development (OLIVEIRA et al., 2009). UNEP defines Cleaner Production as "The continuous application of an integrated environmental strategy to processes, products, and services to increase efficiency and reduce risks to humans and the environment" (UNEP, 2001). 
In Brazil, Cleaner Production has started to be practiced in the mid-1990s, more precisely after the UN Conference on Environment and Development, also known as the Rio 92 (WERNER et al., 2009). According to CNTL (National Center for Cleaner Technologies), cleaner production means application of technical, economic and environmental strategies combined with processes and products, to increase the efficiency in the use of raw materials, water, and energy, through non-generation, minimization or recycling of waste and generated emissions, with environmental, occupational health and economic benefits (CNTL, 2003).

Cleaner Production can be understood as a management methodology whose priority is to save money while maximizing efficiency in the use of energy, raw materials and water, and also minimizing wastes production and enhancing reuse of natural resources (Hinz et al., 2007). By doing so, industries, tend to achieve financial gains (Rensi and Schenini, 2011). According to these authors, Cleaner Production can also be conceptualized as a strategic process within the organization. Moreover, $\mathrm{CP}$ has been defined as an environmental management tool, combined and continued to be applied in services, processes, and products, aiming the reduction of human and nature risks and with clear financial benefits (Pimenta and Marques Júnior, 2006).

There are many potential benefits in CP strategies. To the National Center for Cleaner Technologies, according to Silva et al. (2009), benefits include lower use of water and raw materials, removal or reduction of waste and emissions, higher compliance with legal requirements, enhanced occupational health and safety performance, minimization of risks to employees' health and safety, financial and economic gains, etc. Vilela Júnior and Demajorovic (2006) mention that CP methodology brings gains to the organization, community, environment and to the institutions in charge of environmental control. According to the Brazilian Business Council for Sustainable Development (CEBDS, 2005), the benefits of Cleaner Production are related to the improvement of industrial competitiveness, through the increase of production efficiency and reduction of environmental and social impacts.

\section{APPLiCATION LEVELS OF CP METHODOLOGY TO WASTE MANAGEMENT}

According to CETESB (2009), CP practices can be implanted by any organization, as there are many simple techniques to avoid wastes and prevent environmental impacts. In applying CP strategies to solid waste management, one has to consider four broad principles. The first of them is the non-generation of wastes. However, since this principle is not always technically possible due to particular industrial barriers, a second principle needs to be observed: waste minimization. Third, organizations need to ensure reuse of wastes in its production process. The fourth principle is material recycling, which considers the reuse of leftovers or sub-products. In the event reuse of wastes is impossible inside the company premises, external reuse must be provided. Vilela Júnior and Demajorovic (2006) also report the existence of many possibilities to eliminate/reduce wastes and improve environmental performance. The National Council of Clean Technologies (CNTL, 2003) argues that CP opportunities should take into account the scales of priorities of waste generation and prevention in the firm, which can be divided into three broad levels of implementation, as illustrated in Figure 1.

As shown in Figure 1, the identification of opportunities to the improvement of a company's environmental performance can range from level 1 to levels 2 and 3 (ARAÚJO, 2002). Level 1 refers to a reduction of waste and emissions in the source, considering modifications in the product/service and process. Product changes involve substitutions, redraw of existing products and sub-products productions; likewise, modifications in the process include good practices, raw material substitution, energy sources and technological exchange. Running out of possibilities of waste reductions in the source, a company can move to level 2 , in which alternative internal recycling are sought after. In level 2 , a company tries to reincorporate particular materials and wastes back into the production process, thus reducing the consumption of new raw materials (CEBDS, 2005). In the event all possibilities of reducing wastes and maximizing recycling in levels 1 and 2 are depleted, a company can adopt level 3 $\mathrm{CP}$ actions, which targets recycling and waste minimization outside the industry premises.

\section{IMPLEMENTATION OF CP STRATEGIES}

The implementation of Cleaner Production strategies assumes innovation, competitiveness and social and environmental responsibility, as it is based on the prevention of wastes in the source and the pursuit of a more sustainable process (WERNER et al.,2009). To do so, UNEP has proposed a 5-step methodology, as presented in Table 1. 


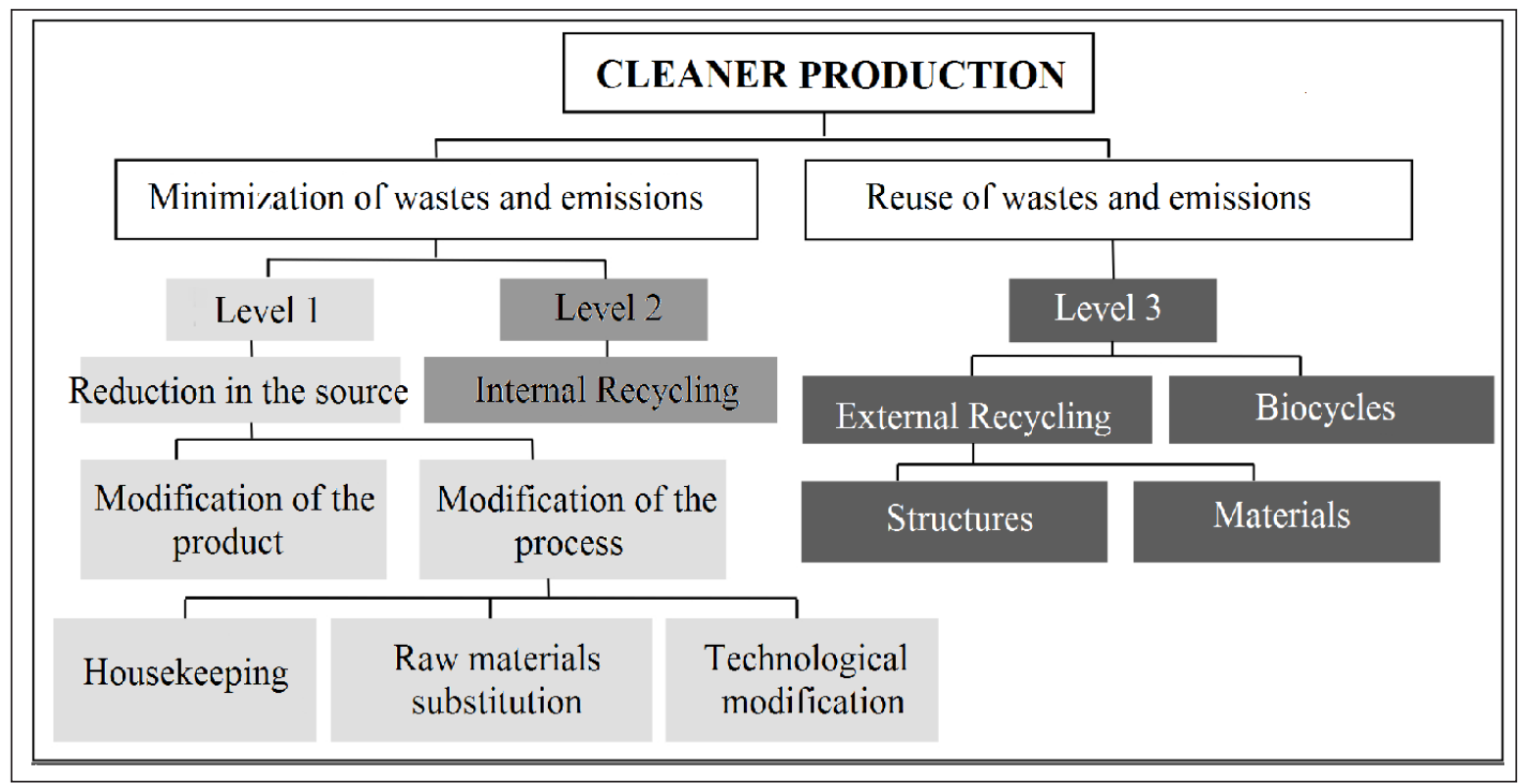

Figure 1 - Levels of CP implementation

Source: Adapted from CNTL (2003)

Table 1 - Cleaner Production Methodology proposed by UNEP

\begin{tabular}{|c|c|}
\hline Steps & Description \\
\hline 1 - Planning and Organization & $\begin{array}{l}\text { - Obtain the commitment of the high administration. } \\
\text { - Get the participation and motivation of staff, through the awareness } \\
\text { of employees. } \\
\text { - Constitute CP teams, with people from different departments who } \\
\text { know the company well. } \\
\text { - Define the program's objective, goals, scope, and activities. }\end{array}$ \\
\hline 2 - Pre Evaluation and Diagnosis & $\begin{array}{l}\text { - Prepare a flowchart of the productive process (raw material, input, } \\
\text { and products). } \\
\text { - Analyze all environmental aspects and impacts to point out the } \\
\text { company situation regarding environmental questions. } \\
\text { - Collect data and information that help in the process description. } \\
\text { Evaluate the entrance and exit of inputs and materials to track critical } \\
\text { points of waste production and its causes. } \\
\text { - Select evaluation foci, gathering environmental aspects with the } \\
\text { company's interests. }\end{array}$ \\
\hline 3 - Evaluation & $\begin{array}{l}\text { - Analyze the causes of waste production. } \\
\text { - Identify and eliminate barriers which make the program development } \\
\text { difficult. } \\
\text { - Identify CP opportunities that aim to avoid waste production and to } \\
\text { improve the environmental performance of the activity. }\end{array}$ \\
\hline $\begin{array}{c}\text { 4- Technical, Economic and } \\
\text { Environmental Viability }\end{array}$ & $\begin{array}{l}\text { - Study the technical viability of CP opportunities. } \\
\text { - Evaluate the environmental viability to determine positives and } \\
\text { negatives impacts of particular CP opportunities. } \\
\text { - Analyze the economic viability of CP opportunities. } \\
\text { - Select CP foci after analyzing the viability of identified opportunities. }\end{array}$ \\
\hline 5 - Implementation and Continuity & $\begin{array}{l}\text { - Create a plan of implantation for CP opportunities. } \\
\text { - Implement the chosen CP opportunities. } \\
\text { Evaluate and monitor the efficiency of implemented CP opportunities. } \\
\text { - Give the CP program a sequence and seek its continuous } \\
\text { improvement. }\end{array}$ \\
\hline
\end{tabular}

Source: SILVA (2009) 
The first step of Planning and Organizing has the main goal of obtaining the company's high administration commitment, the constitution of a $\mathrm{CP}$ team, raising awareness and motivating employees, and, finally, the definition of program objective and goals. In the step of Pre-Evaluation and Diagnosis, the activities developed by the company are studied and diagnosed through the elaboration of a production flowchart, the analysis of environmental aspects and impacts, the collection of data and information that may help in the evaluation, the study of inputs and outputs of materials and energy to track critical points of waste production and its causes, and, finally, the definition of the evaluation scope, which identifies locations where CP actions are needed. The goal of the Evaluation step is to analyze waste production causes, identify and eliminate barriers and verify $\mathrm{CP}$ opportunities. Once the opportunities for improvement are gathered, the possibilities of implementation must be verified. The fourth Viability Step must then analyze the technical, economic and environmental aspects, to further inform the selection of CP actions. The final Implementation and Continuity Step consists of the elaboration of a CP opportunities plan and its actual implementation, as well as of a monitoring program and the pursuit of continuous improvement.

Very few studies have analyzed the extent to which such steps are mirrored in Brazilian industries, let alone within its textile sector fraction. The Brazilian Business Council for Sustainable Development (CEBDS, 2005) reports that, while CP methodology has many benefits, many industries do not fully embed $\mathrm{CP}$ in its fabric, due to the financial costs of a number of environmental solutions.

\section{METHODOLOGY}

To further understand the extent to which textile industries adopt CP strategies, this research focused on the case of a medium-sized textile industry in the state of Minas Gerais, Brazil. For the company classification into micro, small, medium or large, it was chosen the criterion used by the Service of Support to Micro and Small Companies (Serviço de Apoio às Micro e Pequenas Empresas - SEBRAE), which is based on hired employees. Table 2 shows the categorization of industrial size, according to the number of employees adopted by SEBRAE.

Table 2 - Classification of industries according to number of employees

\begin{tabular}{c|c|c|c}
\hline Micro & Small & Medium & Large \\
\hline Until 19 & 20 to 99 & 100 to 499 & More than 499 \\
\hline
\end{tabular}

Source: SEBRAE (2009)

The industry studied is located in the metropolitan area of Belo Horizonte and, at the time of the study, had 170 employees involved in the production of: cotton yarn (100\%), polyester yarn (33\%) with cotton $(67 \%)$ and yarn 8 - a yarn produced using cotton waste $(60 \%)$ and pure cotton $(40 \%)$, destined for the cloth production with inferior quality, such as those used for making dishes cloths. In addition to the yarns, the studied industry also made plain cloth, that is, without embroidery and applications. The choice of the company was due to the fact that it is medium-size, according to SEBRAE, and presents a complete textile process, that is, from yarns to cloth, that allowed a better development of the research. The data collection was based on face-to-face interviews and visits to the industry premises.

The CP analysis of the chosen industry was, initially, proposed to its directors. After the technical details and explanations about the academic objectives of this proposal, the leaders were readily favorable to collaborate in this study allowing access to the premises, documents and its technical staff. After the authorization for the case study, a literature review of the $\mathrm{CP}$ options to be applied in the textile industries. It revealed that BARBALHO (2008), CETESB (2009), GIANNETTI and ALMEIDA (2006) and MONTEIRO (2004) provide a sound basis to design a Checklist of Desirable CP Opportunities in Textile Industries. Such a checklist, presented in Table 3, covers the many phases and activities of a textile industry. 
Table 3 - Check-list of CP opportunities to textile industries

\begin{tabular}{|c|c|c|}
\hline \multicolumn{2}{|c|}{ Options of $\mathrm{CP}$} & Description \\
\hline \multirow{2}{*}{$\begin{array}{l}\text { Raw material } \\
\text { substitution }\end{array}$} & Cotton & Replacement of used cotton by another with superior quality. \\
\hline & Polyester & Exchange of mineral polyester by synthetic. \\
\hline \multirow{9}{*}{ Inputs substitution } & Enzyme & Replacement of enzyme by hydrogen peroxide. \\
\hline & \multirow{2}{*}{ Dyes } & Change of dyes that have metal in a molecule. \\
\hline & & Use of reactive dyes that require low concentrations of salt. \\
\hline & $\begin{array}{l}\text { Sodium hypochlorite } \\
\text { and sodium chlorite }\end{array}$ & $\begin{array}{l}\text { Replacement of Sodium hypochlorite and sodium chlorite by } \\
\text { hydrogen peroxide. }\end{array}$ \\
\hline & Acetic Acid & Alteration of acetic acid by organic acid. \\
\hline & Sodium Dichromate & Exchange of sodium dichromate as an oxidant. \\
\hline & Kerosene & Change of kerosene by organic solvents. \\
\hline & Urea & Reduction of the amount of urea used in the stamping process. \\
\hline & Raw natural starch & Modification of raw natural starch by soluble starch. \\
\hline \multirow{4}{*}{ Inputs substitution } & $\begin{array}{l}\text { Chlorofluorocarbons } \\
\text { (CFCs) }\end{array}$ & $\begin{array}{c}\text { Replacement of Chlorofluorocarbons (CFCs) by } \\
\text { hydrochlorofluorocarbons (HCFCs) and hydrofluorocarbons } \\
\text { (HFCs). }\end{array}$ \\
\hline & $\begin{array}{l}\text { Formaldehyde-based } \\
\text { fasteners }\end{array}$ & $\begin{array}{c}\text { Use's restriction of formaldehyde-based fasteners } \\
\text { Adoption of cationic fasteners. }\end{array}$ \\
\hline & Surfactants & Containment of the use of surfactants in washes after stamping. \\
\hline & Phosphate & Avoidance of phosphate use. \\
\hline \multirow{5}{*}{$\begin{array}{l}\text { Exchange of } \\
\text { productive } \\
\text { technology }\end{array}$} & Blendomatic & Adoption of a machine that automatically mixes raw material. \\
\hline & Open-end (machine) & $\begin{array}{c}\text { Substitution of the conventional process (ring spinning) by the } \\
\text { open-end spinner. }\end{array}$ \\
\hline & Splicing of yarns & $\begin{array}{c}\text { Adoption of an automatic system for splicing of yarns in the } \\
\text { productive process. }\end{array}$ \\
\hline & Rubber kitchen & Change from manual rubber kitchen to automatic. \\
\hline & Ink kitchen & Change from manual ink kitchen to automatic. \\
\hline \multirow{3}{*}{$\begin{array}{l}\text { Equipment } \\
\text { modification }\end{array}$} & Rubber Tanks & Dimensionament review of rubber tanks. \\
\hline & Stamping & $\begin{array}{l}\text { Decrease the length of the print hose feed hose to reduce material } \\
\text { loss. }\end{array}$ \\
\hline & Boilers & Substitution of boilers with oil by wood or natural gas boilers. \\
\hline $\begin{array}{l}\text { Subproducts } \\
\text { production }\end{array}$ & Tow and retail & Use of tow and retail generated to make sub-products. \\
\hline $\begin{array}{c}\text { Product } \\
\text { Modification }\end{array}$ & Fabric & Change of product specification. \\
\hline \multirow{2}{*}{ Extern Recycling } & Oil & Dispatch of used oil to redefine. \\
\hline & $\begin{array}{c}\text { Tow, paper, plastic and } \\
\text { metal scrap }\end{array}$ & Adoption of external recycling with due registration. \\
\hline
\end{tabular}


Table 3 - continuation...

\begin{tabular}{|c|c|c|}
\hline \multicolumn{2}{|c|}{ Options of CP } & Description \\
\hline \multirow{5}{*}{ Recuperation } & \multirow{2}{*}{ Cotton waste } & Installation of a cotton waste suction system on the floor. \\
\hline & & Use of cotton waste recovery machine. \\
\hline & Rubber & Implantation of used rubber recovery system. \\
\hline & Caustic soda & Recovery and recirculation of caustic soda in the process. \\
\hline & Fabric & Adoption of fabric recovery machine. \\
\hline \multirow{7}{*}{$\begin{array}{l}\text { Better process } \\
\text { control }\end{array}$} & \multirow{2}{*}{ Production } & Documented standardization of procedures and work routines. \\
\hline & & Use of statistic in quality controls. \\
\hline & Management of goods & $\begin{array}{l}\text { Use of pre-defined environmental controls and procedures for } \\
\text { acquiring, receiving and stocking goods. }\end{array}$ \\
\hline & Training & $\begin{array}{l}\text { Improvements in the control of the training performed and } \\
\text { revision of training are planning to be done by function. }\end{array}$ \\
\hline & Chemical products & $\begin{array}{l}\text { Establishment of quality control of activities related to chemical } \\
\text { products }\end{array}$ \\
\hline & Automatic doser & Automatic dosing device for chemical products \\
\hline & $\begin{array}{l}\text { Distribution of } \\
\text { chemical products }\end{array}$ & $\begin{array}{l}\text { Implementation of direct distribution tubes of chemical products } \\
\text { in the sectors. }\end{array}$ \\
\hline \multirow{8}{*}{$\begin{array}{c}\text { Good operational } \\
\text { and administrative } \\
\text { practices }\end{array}$} & $\begin{array}{l}\text { Proper operation of } \\
\text { equipment }\end{array}$ & $\begin{array}{c}\text { Periodic review of standard operating procedures } \\
\text { Periodic recycling of operational training }\end{array}$ \\
\hline & $\begin{array}{l}\text { Equipment } \\
\text { maintenance }\end{array}$ & Implantation of predictive maintenance system in equipments \\
\hline & Chemical products & Reduced use of chemicals \\
\hline & Leaks and/or spills & Elimination of leaks and/or spills \\
\hline & Bath ratio & Use of low bath ratios (higher dye yield) \\
\hline & Laboratory "chapel" & Adoption of chapel in the dye laboratory scales \\
\hline & Layout & Alteration of layout and increasing physical space \\
\hline & $\begin{array}{l}\text { Solid waste } \\
\text { management }\end{array}$ & Implementation of a solid waste management program \\
\hline \multirow{8}{*}{$\begin{array}{c}\text { Good operational } \\
\text { and administrative } \\
\text { practices }\end{array}$} & Selective collect & Use of selective collect in operational and administrative sectors \\
\hline & Papers & $\begin{array}{l}\text { Replacement of materials printed on paper by electronic media. } \\
\text { Reuse the back side of the paper when possible }\end{array}$ \\
\hline & Disposable plastic cups & Exchange of disposable plastic cups by mug or bottle for water \\
\hline & $\begin{array}{l}\text { Tow used in } \\
\text { maintenance }\end{array}$ & $\begin{array}{l}\text { Adoption of a flannel reuse system (tissue flaps) used in } \\
\text { mechanical maintenance }\end{array}$ \\
\hline & Packaging & Application of returnable packaging system \\
\hline & Press & $\begin{array}{l}\text { Use of press to reduce the waste volume to be stored and } \\
\text { transported }\end{array}$ \\
\hline & Internal organization & $\begin{array}{c}\text { Improvements in internal organization (adoption of " } 5 \mathrm{~S} \text { " } \\
\text { practices) }\end{array}$ \\
\hline & $\begin{array}{c}\text { Internal } \\
\text { communication }\end{array}$ & Use of notice board \\
\hline
\end{tabular}


Table 3 - continuation...

\begin{tabular}{|c|c|c|}
\hline \multicolumn{2}{|c|}{ Options of $\mathrm{CP}$} & Description \\
\hline \multirow{10}{*}{$\begin{array}{c}\text { Good operational } \\
\text { and administrative } \\
\text { practices }\end{array}$} & $\begin{array}{c}\text { External } \\
\text { communication }\end{array}$ & $\begin{array}{l}\text { Preparation and distribution of informative leaflet } \\
\text { Creation of mascot for the leaflet }\end{array}$ \\
\hline & Signaling & Improvement and standardization of signaling. \\
\hline & $\begin{array}{c}\text { External } \\
\text { communication }\end{array}$ & $\begin{array}{l}\text { Preparation and distribution of informative leaflet } \\
\text { Creation of mascot for the leaflet }\end{array}$ \\
\hline & Signaling & Improvement and standardization of signaling. \\
\hline & Education & The incentive to employee studies. \\
\hline & $\begin{array}{l}\text { Environmental } \\
\text { education }\end{array}$ & $\begin{array}{c}\text { Sensibilization and environmental conscientization of employees } \\
\text { through the implementation of an Environmental Education Plan } \\
\text { and creation of a standard operating system for environmental } \\
\text { issues }\end{array}$ \\
\hline & $\begin{array}{c}\text { Socio and } \\
\text { environmental actions }\end{array}$ & Implementation of socio-environmental actions \\
\hline & \multirow{2}{*}{$\begin{array}{l}\text { Motivation of } \\
\text { employees }\end{array}$} & $\begin{array}{l}\text { Sensibilization and motivational training } \\
\text { Realization of external training }\end{array}$ \\
\hline & & Reform of the company premises \\
\hline & $\begin{array}{l}\text { Environmental } \\
\quad \text { Software }\end{array}$ & Adoption of environmental software \\
\hline
\end{tabular}

Source: Adapted from BARBALHO (2008), CETESB (2009), GIANNETTI and ALMEIDA (2006) and MONTEIRO (2004).

The verification of the checklist items was based on interviews and visits to industrial premises. In sequence, the relevant $\mathrm{CP}$ options that had not yet been implemented in the industry were presented to the managers in order to further understand their perception of feasibility with respect to implementing those gaps. Results are presented and the discussed in the following sections.

\section{DATA ANALYSIS AND RESULTS}

As a first observation, it was verified that the industry did not have institutionalized a formal $\mathrm{CP}$ program. However, the company was adopting a number of $\mathrm{CP}$ practices in several stages of its production process to promote better efficiency. After analyzing the technical, environmental and economic aspects of the CP opportunities presented in Table 3, it was found that at least $49 \%$ of the checklist items were already in practice in the company in question, even though they were not officially implemented by industrial management with this objective and nomenclature. It should be noted, however, that the company did not have a system for recording and monitoring the initiatives adopted, neither a quantity performance evaluation mechanism for each of the "CP initiatives adopted". Table 4 below lists the CP opportunities that were found to be active in the industry. 
Table 4 - CP opportunities already applied in the case study of the textile industry

\begin{tabular}{|c|c|}
\hline & CP options \\
\hline \multirow{13}{*}{ Inputs substitution } & Replacement of enzyme by hydrogen peroxide \\
\hline & Change of dyes that have metal in the molecule. \\
\hline & Use of reactive dyes that require low concentrations of salt. \\
\hline & Replacement of Sodium hypochlorite and sodium chlorite by hydrogen peroxide. \\
\hline & \begin{tabular}{|l} 
Alteration of acetic acid by organic acid. \\
\end{tabular} \\
\hline & Exchange of sodium dichromate as an oxidant. \\
\hline & Change of kerosene by organic solvents. \\
\hline & Reduction of the amount of urea used in the stamping process. \\
\hline & Modification of raw natural starch by soluble starch. \\
\hline & $\begin{array}{l}\text { Replacement of Chlorofluorocarbons (CFCs) by hydrochlorofluorocarbons } \\
\text { (HCFCs) and hydrofluorocarbons (HFCs). }\end{array}$ \\
\hline & $\begin{array}{l}\text { Use's restriction of formaldehyde-based fasteners } \\
\text { Adoption of cationic fasteners. }\end{array}$ \\
\hline & Containment of the use of surfactants in washes after stamping. \\
\hline & Avoidance of phosphate use. \\
\hline \multirow{2}{*}{$\begin{array}{l}\text { Exchange of } \\
\text { productive } \\
\text { technology }\end{array}$} & $\begin{array}{l}\text { Substitution of the conventional process (ring spinning) by the open-end } \\
\text { spinner. }\end{array}$ \\
\hline & Adoption of an automatic system for splicing of yarns in the productive process. \\
\hline \multirow{2}{*}{$\begin{array}{l}\text { Equipment } \\
\text { modification }\end{array}$} & Dimensionament review of rubber tanks \\
\hline & Decrease the length of the print hose feed hose \\
\hline $\begin{array}{l}\text { Subproducts } \\
\text { production }\end{array}$ & Use of tow and retail generated to make sub-products. \\
\hline Extern Recycling & External recycling of tow, paper, plastic and metal scrap. \\
\hline \multirow{2}{*}{ Recuperation } & Installation of a cotton waste recovery machine. \\
\hline & Implantation of used rubber recovery system. \\
\hline \multirow{3}{*}{$\begin{array}{l}\text { Better process } \\
\text { control }\end{array}$} & Documented standardization of procedures and work routines. \\
\hline & Use of statistic in quality controls. \\
\hline & $\begin{array}{l}\text { Improvements in the control of the training performed and revision of training are } \\
\text { planning to be done by function. }\end{array}$ \\
\hline \multirow{7}{*}{$\begin{array}{c}\text { Good } \\
\text { operational and } \\
\text { administrative } \\
\text { practices }\end{array}$} & $\begin{array}{l}\text { Proper operation of equipment (periodic review of standard operating procedures } \\
\text { and periodic recycling of training) }\end{array}$ \\
\hline & Reduced use of chemicals \\
\hline & Elimination of leaks and/or spills \\
\hline & Use of low bath ratios (higher dye yield) \\
\hline & Reduce paper consumption \\
\hline & Exchange of disposable plastic cups by mug or bottle for water \\
\hline & Adoption of a press to reduce the volume of waste to be handled. \\
\hline
\end{tabular}

Subsequently, that the study analyzed the feasibility of implementing the $\mathrm{CP}$ options not yet implemented in the industry in question, based mainly on the managers 'perception. It was observed that $41 \%$ of them were considered unfeasible and that $59 \%$ were feasible to be implemented from a technical, environmental and/or economic point of view. In Table 5, some situations regarding the options of CP considered not feasible in the study are presented. 
Table 5 - CP opportunities considered unfeasible for the industry analyzed

\begin{tabular}{c|c}
\hline \multicolumn{2}{c}{ Options of CP } \\
\hline \multirow{2}{*}{ Raw material substitution } & Replacement of used cotton by another with superior quality. \\
\cline { 2 - 2 } & Exchange of mineral polyester by synthetic. \\
\hline \multirow{2}{*}{$\begin{array}{c}\text { Exchange of productive } \\
\text { technology }\end{array}$} & $\begin{array}{c}\text { Adoption of a machine (Blendomatic) that automatically mixes raw } \\
\text { material. }\end{array}$ \\
\cline { 2 - 2 } & Change from manual rubber kitchen to automatic. \\
\hline Equipment modification & Change of ink kitchen from manual to automatic. \\
\hline Product Modification & Cubstitution of boilers with oil by wood or natural gas boilers. \\
\hline \multirow{2}{*}{ Recuperation } & Installation of a cotton waste suction system on the floor. \\
\cline { 2 - 2 } & Recovery and recirculation of caustic soda in the productive process. \\
\hline Better process control & Adoption of fabric recovery machine. \\
\hline $\begin{array}{c}\text { Good operational and } \\
\text { administrative practices }\end{array}$ & $\begin{array}{c}\text { Implementation of direct distribution tubes of chemical products in the } \\
\text { sectors. }\end{array}$ \\
\cline { 2 - 2 } & Alteration of layout and increasing physical space \\
\hline
\end{tabular}

The CP opportunity for the substitution of raw material (cotton) for higher quality input was evaluated in the study as economically unfeasible, since the type of cotton used in the industrial process fully met the specifications required, because it had lower purchasing power and generated a type of waste, called "cotton wool or lice", that was recovered in specific machinery within the company itself. After going through the recovery process, the cotton waste, consisting mainly of husks and seeds, were used as food supplement for cattle and used outside the company. The change of the mineral polyester by the synthetic type was defined in the study as not feasible under the technical and economic aspects because the synthetic polyester presents less resistance in the production and higher purchasing value than the mineral. Due to the high investment value for the acquisition of new machinery, the low waste generation in the production process and the low operation cost, the acquisition of a blend magic, one automatic rubber and ink kitchen were not considered feasible initiatives for the industry studied, as it could jeopardize the industry profitability. The use of natural gas boiler was also not considered feasible, because the municipality where the industry was located did not have this resource for industrial use, despite passing in the operational vicinity, a branch of the gas pipeline of the company that holds this concession.

Regarding the modification of the industry's product, in the case of the fabric, this action also was considered technically unfeasible, since the alteration of fabric characteristics of the fabric compromises the specifications required by the customers, due to the specifics, necessities and use, therefore this measure was not proposal. The recovery of caustic soda used to remove starch, to reveal and to fix the fabric's colors also was considered technically unfeasible, because the recovery system of this product happens in the process of mercerization, and the industry of the study does not have such stage in its productive structure. Due to the industry's old machinery and low generation of cotton waste and the low operating cost of waste collection, the installation of an underground suction system for this material from the industry environment was also regarded as technically and economically unfeasible, as it would require high financial investments with unclear benefits.

The acquisition of machinery for the recovery of fabric flaps was also considered technically and economically unfeasible, since the recovered fiber is only possible to make socks, scarves, gloves, and others similar things, which was not the production focus of this industry, in addition to the high investment value for the purchase of the machinery in question. It is noteworthy that the waste generated (fabric flaps) were easily sold to various customers. Therefore, it was not considered an environmental and operational problem.

The implementation of an automatic system of distribution of chemical products directly in the machines of the productive process of the industry studied was evaluated was technically unfeasible, 
since such inputs always demand laboratory preparation before being used in the production line. Due to the small displacement of raw materials and semi-finished products in the production process and the size of the company, in addition to the lack of physical space and the existence of a watercourse within the facilities of the industry studied, the layout change does not justified, rendering it unfeasible.

In order to implement a distribution system for finished products with the use of returnable packaging based on reverse logistics, according to the Nacional Solid Waste Policy (2010), it would be necessary to adopt used materials in more resistant packaging that would justify its return to the company. With this measure, it would have increased the value of the packaging and there would be greater expenses with the freight for its return. It is noteworthy that the industrial unit studied used recycled flat plastics to pack its products. Thus, it was considered the option of using returnable packaging as being economically unviable, despite the environmental gain that its use represents.

On the other hand, the main CP opportunities identified as viable refer to simple actions, resulting from good operational and administrative practices, with low implementation costs and easier execution. After the preliminary assessment of the technical, environmental and economic feasibility, the following CP opportunities to be employed in the industry studied were identified, which are described in Table 6.

Table 6 - Viable P \& L opportunities for the industry studied

\begin{tabular}{|c|c|}
\hline \multicolumn{2}{|r|}{ Viable P \& L opportunities } \\
\hline $\begin{array}{c}\text { Good operacional } \\
\text { and administrative } \\
\text { practices }\end{array}$ & $\begin{array}{l}\text {-External recycling and recovery (e.g. shipment of used lubricating oil for } \\
\text { refining); } \\
\text { - Creation of a standard operating procedure for the management of } \\
\text { goods; } \\
\text { - Establishment of quality control of activities related to chemicals; } \\
\text { - Installation of automatic dosing of chemicals used in the process; }\end{array}$ \\
\hline $\begin{array}{c}\text { Good operational } \\
\text { and administrative } \\
\text { practices }\end{array}$ & $\begin{array}{l}\text { - Implementation of predictive maintenance system in equipment; } \\
\text { - Adoption of "chapel" in the dye laboratory scales; } \\
\text { - Implementation of a Solid Waste Management Program; } \\
\text { - Use of selective waste collection in the operational and administrative } \\
\text { sectors; } \\
\text { - Adoption of a reuse system for flannels (fabric flaps) used in } \\
\text { mechanical maintenance; } \\
\text { - Improvements in internal organization (adoption of "5S" practices); } \\
\text { - Use of notice board (improvement in internal communication); } \\
\text { - Preparation and distribution of information leaflet on operational and } \\
\text { environmental issues (evolution of external communication); } \\
\text { - Improvement and standardization of internal signaling; } \\
\text { - Incentive to the studies of the employees; } \\
\text { - Introduction of Environmental Education Program for employees and } \\
\text { neighbors; } \\
\text {-Implementation of socio-environmental actions; } \\
\text { - Motivation of employees in environmental issues (motivational training } \\
\text { and reform of the company's physical facilities); } \\
\text { - Adoption of environmental software. }\end{array}$ \\
\hline
\end{tabular}

Based on a rather simplistic economic analysis of the budget of the specified items necessary to implement the $\mathrm{CP}$ opportunities defined as viable for the industry, this study found that the industry would require an immediate investment of approximately R $\$ 314,000.00$ (about US $\$ 100 \mathrm{k}$, in October 2017 ) and of approximately R $\$ 11,750.00$ (about US $\$ 4 \mathrm{k}$, in October 2017) annually to monitor the results of the methodology. It is worth mentioning that the main investment in the unit was related to the revitalization and general retrofitting of the company's machinery, which had out of date technology.

Due to the immediate support of industry leadership in the development of this study, it was noticed that the options for CP raised and considered viable would be analyzed by the administration, with a great possibility that part of them would be implemented, since many of them were of simple character and resulted in the implementation of good operating practice and know-how already acquired. 
It should be noted, however, that, out of all the opportunities considered viable here, only a few of them had an environmental character per se. With simple initiatives of operational nature, the industry could easily implement CP strategies; by, for example, training employees on environmental issues, implementing local socio-environmental actions, , institutionalizing internal communications with a focus on $\mathrm{CP}$ initiatives, etc. However, it would be necessary to constantly monitor the results obtained with such initiatives, to make sure they would actually translate into eco-efficiency.

\section{FINAL CONSIDERATIONS}

This study analyzed the implementation of Cleaner Production strategies in a medium-sized industry in the textile sector of Minas Gerais, based on a checklist drawn from the literature. Compliance with the checklist items was analyzed through interviews and visits to the industry premises. It was noted that $41 \%$ of the initiatives on the Checklist, considered as CP for the textile industry, were unfeasible; while $59 \%$ of them were more clearly viable to be implemented from a technical, administrative, environmental and/or economic point of view. It was also observed that, due to the installed production capacity of the company and to the quantity and types of solid wastes it generated, some $\mathrm{CP}$ options become technically and economically unfeasible because, in the perception of managers, they would demand a high investment that could jeopardize the company profitability. With regard to the main wastes generated by the company, it is worth mentioning that these are non-dangerous and are relatively easy to dispose of. Even so, based on the results, it was observed that the use of the CP actions could decrease waste generation in the source and also mitigate environmental impacts. It was also noticed that the adoption of CP opportunities in the industry is mainly related to low-cost actions that do not demand complicated equipment and/or programs.

Overall, the results obtained here corroborate the argument that the implementation of $\mathrm{CP}$ actions (arguably for any type of industry and not only for those in the textile sector) tends to be partially implemented, giving the existence of numerous financial barriers. A robust implementation of $\mathrm{CP}$ strategy is further complicated by the lack of guidelines and specific information about the industries' many processes and activities. Therefore, in deciding for whatever CP opportunity, managers need to carefully consider their technical, environmental and financial context.

\section{REFERENCES}

Araújo, AF. A aplicação da metodologia de produção mais limpa: estudo em uma empresa do setor de construção civil. 2002. 121 f. Dissertação (Mestrado em Engenharia de Produção) - Programa de Pós-Graduação em Engenharia de Produção, Universidade Federal de Santa Catarina, Florianópolis, 2002.

CNTL. O que é produção mais limpa? PortoAlegre: Centro Nacional de Tecnologias Limpas SENAI-RS/ UNIDO/UNEP; 2003.

CETESB. Guia Técnico Ambiental da Indústria Têxtil - Série P+L. 2009. Disponível em: < www.sinditextilsp. org.br/guia_p\%2B1.pdf.pdf>. Acesso em: 09 mai. 2017.

CEBDS. Guia da produção mais limpa: faça você mesmo. Rio de Janeiro, 2005. Disponível em: < http:// cebds.org/wp-content/uploads/2016/09/Guia-Pra\%CC\%81tico-de-PmaisL.pdf>. Acesso em: 09 mai. 2017.

Giannetti BF, Almeida CMVB. Ecologia industrial: conceitos, ferramentas e aplicações. São Paulo: Edgard Blucher; 2006. p. 1-84.

Giffoni PO, Lange LC. A utilização de borra de fosfato como matéria-prima alternativa para a fabricação de tijolos. 2005; 10(2): 128-136. 
Hilson G. Defining "cleaner production" and "pollution prevention" in the mining context. Minerals Engineering. 2003 ; 16(4): 305-321.

Hinza RTP, Valentina LVD, Franco AC. Monitorando o desempenho ambiental das organizações através da produção mais limpa ou pela avaliação do ciclo de vida. Revista Produção Online. 2007; 7(3).

Monteiro F. Procedimento do sistema de gestão: gerenciamento de resíduos. Sete Lagoas: CEDRO; 2004.

Oliveira EB et al. Desenvolvimento sustentável e produção mais limpa: estudo de caso em uma empresa do setor moveleiro. ConTexto. 2009; 9(16): 1-12.

Pimenta HCD, Marques Júnior S. Modelo de gerenciamento de resíduos sólidos: um estudo de caso na indústria de panificação em Natal-RN. In: XXVI Encontro Nacional de Engenharia de Produção. Fortaleza, 2006. Disponível em: < http://www.abepro.org.br/biblioteca/enegep2006_tr520347_8416.pdf >. Acesso em: 09 mai 2017.

Philippi AJr, Roméro MA, Bruna GC. Curso de gestão ambiental. Barueri, SP: Editora Manole; 2004. p. 154210.

PNUMA. A produção mais limpa e o consumo sustentável na América Latina e Caribe. São Paulo, 2004. Disponível em: < http://www.cqgp.sp.gov.br/gt_licitacoes/publicacoes/AProducaoMaisLimpaeoConsumoSustentavelNaALeC.pdf>. Acesso em: 09 mai 2017.

Rensi F, Schenini PC. Produção mais limpa. Revista de Ciências da Administração. 2006; 8(16): 1-26.

SEBRAE. Critérios de classificação de empresas. 2009. Disponível em: <http://www.sebrae-sc.com.br/ideais/ default.asp?vcdtexto=4154\&\%5E\%5E >. Acesso em: 09 mai 2017.

Silva Filho JCG, Sicsú AB. Produção Mais Limpa: uma ferramenta de gestão ambiental aplicada às empresas nacionais. In: XXII Encontro Nacional de Engenharia de Produção. Ouro Preto, 2003. Disponível em: < http://www.abepro.org.br/biblioteca/ENEGEP2003_TR1005_0001.pdf>. Acesso em: 09 mai 2017.

Silva MP. Estudo da viabilidade de implantação de práticas de produção mais limpa em laboratórios da Fundação Ezequiel Dias - MG. 2009. 168 f. Dissertação (Mestrado em Engenharia Ambiental) - Programa de Pós-Graduação em Engenharia Ambiental, Universidade Federal de Ouro Preto, Ouro Preto, 2009.

Silva RB. et al. Aplicação da produção mais limpa no processo de clarificação do caldo de cana para a produção de açúcar. Revista GEPROS. 2009; 4(1): 60-71.

Sisinno CLS. Disposição em aterros controlados de resíduos sólidos industriais não-inertes: avaliação dos componentes tóxicos e implicações para o ambiente e para a saúde humana. Cadernos de Saúde Pública. 2008; 19(2): 369-374.

United Nations Environment Programme (UNEP). Implementation Guidelines for Governments. Paris: UNEP; 2001.

Vendrametto O, Sacomano JB, Chaves LEC, Santos OSS, Oliveira Neto GC. Governança corporativa sustentável e vantagem na implementação da Produção Mais Limpa: um estudo de caso. In: IV Congresso Nacional de Excelência em Gestão. Niterói, 2008. Disponível em: <http://www.inovarse.org/filebrowser/download/8836 >. Acesso em: 09 mai. 2017.

Vivela Júnior A, Demarjorovic J. Modelos e ferramentas de gestão ambiental: desafios e perspectivas para as organizações. São Paulo: Senac; 2006. p. 41-148. 
Wener EM, Bacarji AG, Hall RJ. Produção mais limpa: conceitos e definições metodológicas. SEGeT - Simpósio de Excelência em Gestão e Tecnologia. Cuiabá, 2009. Disponível em: < http://www.aedb.br/seget/ arquivos/artigos09/306_306_PMaisL_Conceitos_e_Definicoes_Metodologicas.pdf >. Acesso em: 09 mai. 2017. 